6-1-2014

\title{
Development and Validation of LC-MS/MS Method for Quantitative Determination of (-)-Securinine in Mouse Plasma
}

\author{
Simuli L. Wabuyele \\ Cleveland State University \\ David Wald \\ Case Western Reserve University \\ Yan Xu \\ Cleveland State University, y.xu@csuohio.edu
}

Follow this and additional works at: https://engagedscholarship.csuohio.edu/scichem_facpub

Part of the Analytical Chemistry Commons

How does access to this work benefit you? Let us know!

\section{Recommended Citation}

Wabuyele, Simuli L.; Wald, David; and Xu, Yan, "Development and Validation of LC-MS/MS Method for Quantitative Determination of (-)-Securinine in Mouse Plasma" (2014). Chemistry Faculty Publications. 182.

https://engagedscholarship.csuohio.edu/scichem_facpub/182

This Article is brought to you for free and open access by the Chemistry Department at EngagedScholarship@CSU. It has been accepted for inclusion in Chemistry Faculty Publications by an authorized administrator of EngagedScholarship@CSU. For more information, please contact library.es@csuohio.edu. 


\title{
Development and validation of LC-MS/MS method for quantitative determination of $(-)$-securinine in mouse plasma
}

\author{
Simuli L. Wabuyele , David Wald , Yan Xu
}

\section{Introduction}

Securinine is a major alkaloid found in the plant leaves of Securinega suffruticosa, a sub-tropical semi-shrub that has been used in traditional Chinese folk medicine [1,2]. (-)-Securinine (SE) has been reported to have a wide range of pharmacological activities such as antagonist of $\gamma-G A B A_{A}$ receptor $[3,4]$, therapeutic agent for the treatment of sequela of poliomyelitis, amyotrophic lateral sclerosis (ALS) and aplastic anemia [5,6], and macrophage activator against Coxiella burnetii [7], or an inhibitor of parasitic (Toxoplasma gondii) proliferation [8]. More recently, SE has been found to induce apoptosis in various human cancer cell lines including HL-60 [9], SW480 [10] and p53-deficient colon cancer cells [11], and promote differentiation in several acute myeloid leukemia (AML) cells lines such as HL-60, THP-1 and OCI-AMLT3, as well as cells from primary leukemic patients [12]. Furthermore, SE has been demonstrated to synergize with other differentiation agents (e.g., all-trans retinoic acid, decitabine, and 1,25-dihydroxyvitamin D3) which are currently used for treatment of AML; hence, SE could be used to enhance the clinical activity and reduce the toxicity of these agents [12].

To support the preclinical and clinical studies of SE, a quantitative analytical method is critically needed for the measurement of the compound in biological specimens. Based on a recent Scifinder ${ }^{\circledR}$ scholar database search, the current analytical methods for SE analysis are mainly qualitative, which include HPLC-UV $[13,14]$, and CE-UV [15]. The only quantitative assay reported for SE is a GC-MS method which lacks adequate sensitivity for analysis of biological samples and has not been validated [16].

In this work, an LC-MS/MS method for quantitative determination of SE in mouse plasma has been developed. Norsecurinine (norSE) was used as the internal standard (IS). A salting-out assisted liquid-liquid extraction (SALLE) procedure was implemented for plasma sample extraction. Separation of SE and IS was carried out on a reverse-phase column and quantification was achieved by positive electrospray ionization tandem mass spectrometry (ESI $\left.{ }^{+}-\mathrm{MS} / \mathrm{MS}\right)$ in multiple-reaction monitoring mode (MRM). The LC-MS/MS method developed for SE analysis has been validated in mouse plasma according to the guidance for industry on bioanalytical method validation by the US Food and Drug Administration (US-FDA) [17] and the white paper of the 2006 bioanalytical 
method validation workshop [18,19], and applied to the measurement of SE in mouse plasma samples from an animal study.

\section{Experimental}

\section{Chemicals and solutions}

(-)-Securinine or SE $\left(\mathrm{C}_{13} \mathrm{H}_{15} \mathrm{NO}_{2}\right.$, CAS Registry Number: 5610 40-2) was obtained from LKT Laboratories (St. Paul, MN, USA). (+)-Norsecurinine or norSE $\left(\mathrm{C}_{12} \mathrm{H}_{13} \mathrm{NO}_{2}\right.$, CAS Registry Number: 25472-13-3) was from Ryan Scientific (Mount Pleasant, SC, USA). Ammonium acetate and dimethyl sulfoxide (DMSO) were from Sigma-Aldrich (St. Louis, MO, USA). HPLC-grade acetonitrile was from Pharmco-AAPER (Shelbyville, KY, USA). Six pooled blank mouse plasmas (Na citrated) with specified lot numbers (1H145302, 1R11-0823a, 1R11-0823b, 1H1453-01, 1R11-MS-Nac-0811 and 1R10-NSA-02) were purchased from Innovative Research (Novi, MI, USA). Deionized water was obtained from an in-house Barnstead NANOpure ${ }^{\mathrm{TM}}$ water purification system (Thermo Scientific, Waltham, MA, USA) with a resistance reading of $18.2 \mathrm{M} \Omega$.

Stock standard solutions of SE $\left(2.00 \mathrm{mg} \mathrm{mL}^{-1}\right)$ and norSE ( $1.20 \mathrm{mg} \mathrm{mL}^{-1}$ ) were prepared individually by dissolving proper amount of each accurately weighed compound in a known volume of DMSO. Aliquots $(20.0 \mu \mathrm{L})$ of the each stock solution were stored at $-80^{\circ} \mathrm{C}$ prior to use. SE working standard solutions (12.0, 24.0, $36.0,120,240,360,1.20 \times 10^{3}, 2.40 \times 10^{3}, 1.08 \times 10^{4}, 1.20 \times 10^{4}$ and $3.60 \times 10^{4} \mathrm{ng} \mathrm{mL}^{-1}$ ) were prepared daily by serial dilution of the stock standard solution of SE with DMSO. Working IS solution $\left(1.20 \times 10^{3} \mathrm{ng} \mathrm{mL}^{-1}\right)$ was prepared by three sequential dilutions $(1 / 10)$ of the stock IS solution in DMSO.

Ammonium acetate solutions $(0.100 \mathrm{M}$ and $2.00 \mathrm{M})$ were prepared by dissolving appropriate amounts of the buffer salt in known volumes of water. $10.0 \mathrm{mM}$ ammonium acetate ( $\mathrm{pH}$ 6.8) was prepared by a $1 / 10$ dilution of the $0.100 \mathrm{M}$ solution with water. The chromatographic mobile phase consisting of $40 \%$ acetonitrile and $60 \% 10.0 \mathrm{mM}$ ammonium acetate was prepared by mixing $200 \mathrm{~mL}$ of acetonitrile with $300 \mathrm{~mL}$ of $10.0 \mathrm{mM}$ ammonium acetate.

\section{Preparation of plasma calibrators and quality controls (QCS)}

SE plasma calibrators $(0.600,1.20,6.00,12.0,60.0,120$ and $\left.600 \mathrm{ng} \mathrm{mL}^{-1}\right)$, QCs $\left(1.80,18.0,540 \mathrm{ng} \mathrm{mL}^{-1}\right)$ and dilution QC $\left(1.80 \times 10^{3} \mathrm{ng} \mathrm{mL}^{-1}\right)$ were prepared by diluting every $50.0 \mu \mathrm{L}$ of the aforementioned SE working standard solutions with $950 \mu \mathrm{L}$ of pooled blank mouse plasma. SE plasma zero calibrator $\left(0.000 \mathrm{ng} \mathrm{mL}^{-1}\right)$ was prepared by diluting $50.0 \mu \mathrm{L}$ of DMSO with $950 \mu \mathrm{L}$ of pooled blank mouse plasma. Aliquots $(100.0 \mu \mathrm{L})$ of plasma calibrators, QCs and dilution QC were kept in $1.50 \mathrm{~mL}$ microcentrifuge tubes (VWR, Radnor, PA, USA) and stored at $-80^{\circ} \mathrm{C}$ before use.

\section{Preparation of plasma samples}

Plasma calibrators, QCs, dilution QC and the mouse plasma samples from animal study (see Section 2.9) were thawed at room temperature. Prior to the sample extraction by SALLE, the mouse plasma samples and dilution QC were subjected to 10-time dilution using pooled blank mouse plasma, then $5.00 \mu \mathrm{L}$ of the working IS solution $\left(1.20 \times 10^{3} \mathrm{ng} \mathrm{mL}^{-1}\right)$ was added to each $100 \mu \mathrm{L}$ of plasma sample except the double blank where $5.00 \mu \mathrm{L}$ of DMSO was added. After vortex mixing, $600 \mu \mathrm{L}$ of cold acetonitrile $\left(-20^{\circ} \mathrm{C}\right)$ and $100 \mu \mathrm{L}$ of $2.00 \mathrm{M}$ ammonium acetate were added sequentially to each plasma sample. The resultant mixture was vortexed for $3 \mathrm{~s}$, and then centrifuged at $15,000 \times \mathrm{g}$ and $4{ }^{\circ} \mathrm{C}$ for $10 \mathrm{~min}$. After centrifugation, $200 \mu \mathrm{L}$ aliquot of supernatant was diluted $1: 1$ with $10.0 \mathrm{mM}$ ammonium acetate ( $\mathrm{pH}$ 6.8) and used directly for LC-MS/MS analysis.

\section{LC-MS/MS system}

The LC-MS/MS instrumentation used for this work consisted of a Shimadzu Prominence UFLC system (Shimadzu, Columbia, $\mathrm{MD}$, USA) and an AB Sciex QTrap 5500 mass spectrometer (AB Sciex, Foster City, CA, USA). The UFLC system included a system controller (CBM-20A), two binary pumps (LC-20AD), a temperature-controlled autosampler (SIL $20 \mathrm{AH}_{\mathrm{T}}$ ) and an online degasser (DGU20A 3 ), and the mass spectrometer came with a Turbo IonSpray source. The UFLC system outlet was connected to the mass spectrometer via high-pressure polyether ether ketone (PEEK) tubing (0.0625 in. o.d. $\times 0.0100$ in. i.d.).

\section{Chromatographic separation}

The chromatographic separation was carried out isocratically under ambient temperature on a reverse-phase Gemini $\mathrm{Nx} \mathrm{C}_{18}$ (2.1 mm i.d $\times 150 \mathrm{~mm}, 5 \mu \mathrm{m}, 110 \AA$ ) column (Phenomenex, Torrance, CA, USA) with an inline VHP filter $(0.5 \mu \mathrm{m}$, stainless steel $)$ from Upchurch Scientific (Oak Harbor, WA, USA). The sample injection volume was $10.0 \mu \mathrm{L}$ and the mobile phase flow rate was $0.200 \mathrm{~mL} \mathrm{~min}^{-1}$. Prior to sample analysis, the column was first equilibrated with at least 20 column volumes of the mobile phase at a flow rate of $0.200 \mathrm{~mL} \mathrm{~min}^{-1}$.

\section{Mass spectrometric detection}

AB Sciex QTrap 5500 tandem mass spectrometer was operated in positive electrospray ionization (ESI+) mode. It was tuned by flow injection analysis of SE ( $\left.250 \mathrm{ng} \mathrm{mL}^{-1}\right)$ and norSE $\left(500 \mathrm{ng} \mathrm{mL}^{-1}\right.$ ) in the mobile phase for both compound-dependent and sourcedependent parameters. The optimized ionization parameters were as follows: curtain (CUR), 20 psi; collision-activated dissociation (CAD) gas, medium; nebulizer gas (GS1), 40 psi; turbo heater gas (GS2), 25 psi; ion spray voltage (IS), $5500 \mathrm{~V}$; source temperature (TEM), $300^{\circ} \mathrm{C}$. High purity nitrogen (99.99\%) was used as the nebulizer, auxiliary, collision and curtain gases. The declustering potential (DP), entrance potential (EP), collision energy (CE) and collision cell exit potential (CXP) were set at 65, 6.0, 30 and $8.0 \mathrm{~V}$ for SE and 80, 7.0, 35, 6.0 V for norSE. Quantification was performed by multiple-reaction-monitoring (MRM) mode with mass transitions $m / z 218.1 \rightarrow 84.1$ for SE, and $m / z 204.1 \rightarrow 70.2$ for norSE. The dwell time for each transition was $300 \mathrm{~ms}$ and the mass resolutions (Q1 and Q3) were set at unit.

\section{Data acquisition and analysis}

Data acquisition and peak integration were carried out by the AB Sciex Analyst ${ }^{\circledR}$ software (version 1.5.2). The linear regression calibration equation was obtained by plotting the mean-peak-area ratios of SE plasma calibrators to those of the IS versus the concentrations of SE calibrators using a weighting factor of $1 / x$ (where $x$ is the nominal concentration of a plasma calibrator).

\section{Stability study}

The stability of SE was investigated using the SE stock solutions (2.00 $\left.\mathrm{mg} \mathrm{mL}^{-1}\right)$, low and high plasma QC samples (1.80, $540 \mathrm{ng} \mathrm{mL}^{-1}$ ), and the stability of norSE was also determined separately using the norSE stock solution $\left(1.20 \mathrm{mg} \mathrm{mL}^{-1}\right)$ and a plasma sample at a concentration of $60.0 \mathrm{ng} \mathrm{mL}^{-1}$. In the latter studies, SE was used as the IS for norSE. 
Stabilities of stock solution and mouse plasma samples were assessed by short-term ( 6 and $24 \mathrm{~h}$ ) standing on bench-top at $23^{\circ} \mathrm{C}$ and in the auto sampler at $4{ }^{\circ} \mathrm{C}$ (post preparative); freeze-and-thaw cycles; and long- term storage at -20 and $-80^{\circ} \mathrm{C}$. The stabilities of SE and norSE were determined by comparing the mean-peak-area ratios of analyte to the IS in the test sample to those of freshly prepared samples, and expressed as percentages.

\section{Animal study}

The LC-MS/MS method developed was applied to the measurement of SE concentrations in the following animal study which had been approved by the Case Western Reserve University Institutional Animal Care and Use Committee (IACUC). BALB/c mice were obtained from Jackson laboratories (Bar Harbor, ME, USA). The mice were randomly housed, and had an average body weight of $25 \mathrm{~g}$ at the time of SE injections. The injectable SE $\left(1 \mathrm{mg} \mathrm{mL}^{-1}\right)$ was prepared in $10 \%$ DMSO aqueous solution which was given to mice as a single-bolus intraperitoneal (i.p.) injection at a dose of $4.00 \mathrm{mg} \mathrm{kg}^{-1}$. The mouse blood samples were collected via ocular puncture into $1.5 \mathrm{~mL}$ microcentrifuge tubes containing heparin as anti-coagulant at the following time points: 0 (pre-dose), 1.5, 3, $7,9,15,30$ and $120 \mathrm{~min}$. For the pre-dose sample, the mouse was injected with only $10 \%$ DMSO aqueous solution without SE. One whole blood sample (ca. $100 \mu \mathrm{L}$ ) was drawn from single mouse at each time point, which was placed in ice immediately. The whole blood samples were processed within $15 \mathrm{~min}$ of collection by centrifugation at $1000 \times \mathrm{g}$ and $4{ }^{\circ} \mathrm{C}$ for $10 \mathrm{~min}$. The harvested plasma samples (ca. $50 \mu \mathrm{L}$ each) were stored at $-80^{\circ} \mathrm{C}$ until analysis.

\section{Results and discussion}

Internal standard (IS)

Structural analog of SE was used as IS since stable heavy isotope of SE was not available. Initially, several custom-synthesized SE analogs were tested; however, most of the analogs chosen contained trace amount of SE due to the use of SE as precursor in synthetic routes. NorSE was eventually chosen since it was free of SE. NorSE is structurally similar to SE, but differs only by one $-\mathrm{CH}_{2}$ unit, which has a pyrrolidinly instead of piperidinyl ring.

\section{Analyte solubility}

According to the Sci-Finder ${ }^{\circledR}$ Scholar database search, the $\log P$ values of SE and norSE are -0.969 and -1.497 respectively. These compounds should be hydrophilic rather than hydrophobic. However, we found them to be difficult to dissolve in either aqueous solution or plasma directly, which is probably attributed to their large rigid ring structures. Although ethanol can dissolve these compounds, it can cause protein precipitation in plasma, resulting in poor analytical reproducibility. The suitable solvent to dissolve both SE and norSE is DMSO. In this work, the SE and norSE working standard solutions were prepared in 100\% DMSO, which was diluted to $\leq 10 \%$ DMSO in plasma calibrators and QC samples to ensure no protein precipitation from plasma matrices [20].

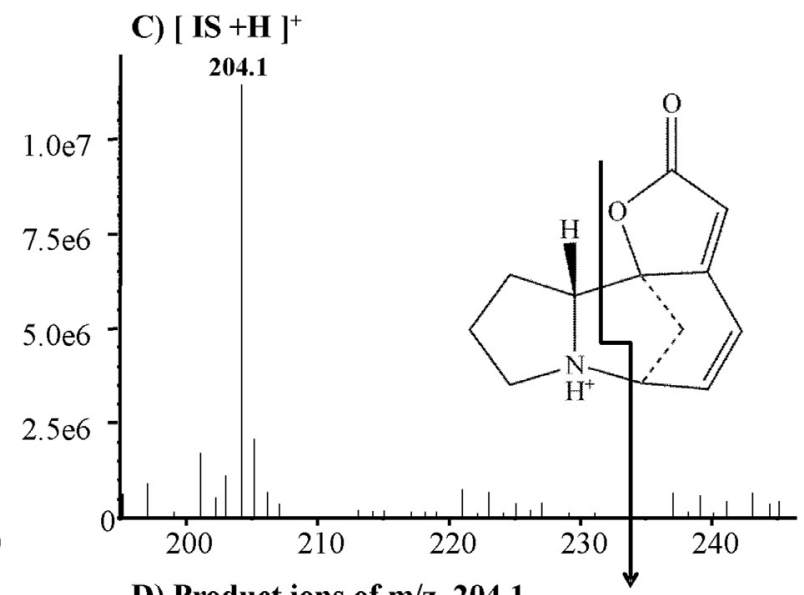

D) Product ions of $\mathrm{m} / \mathrm{z} 204.1$

B) Product ions of $\mathrm{m} / \mathrm{z} 218.1$
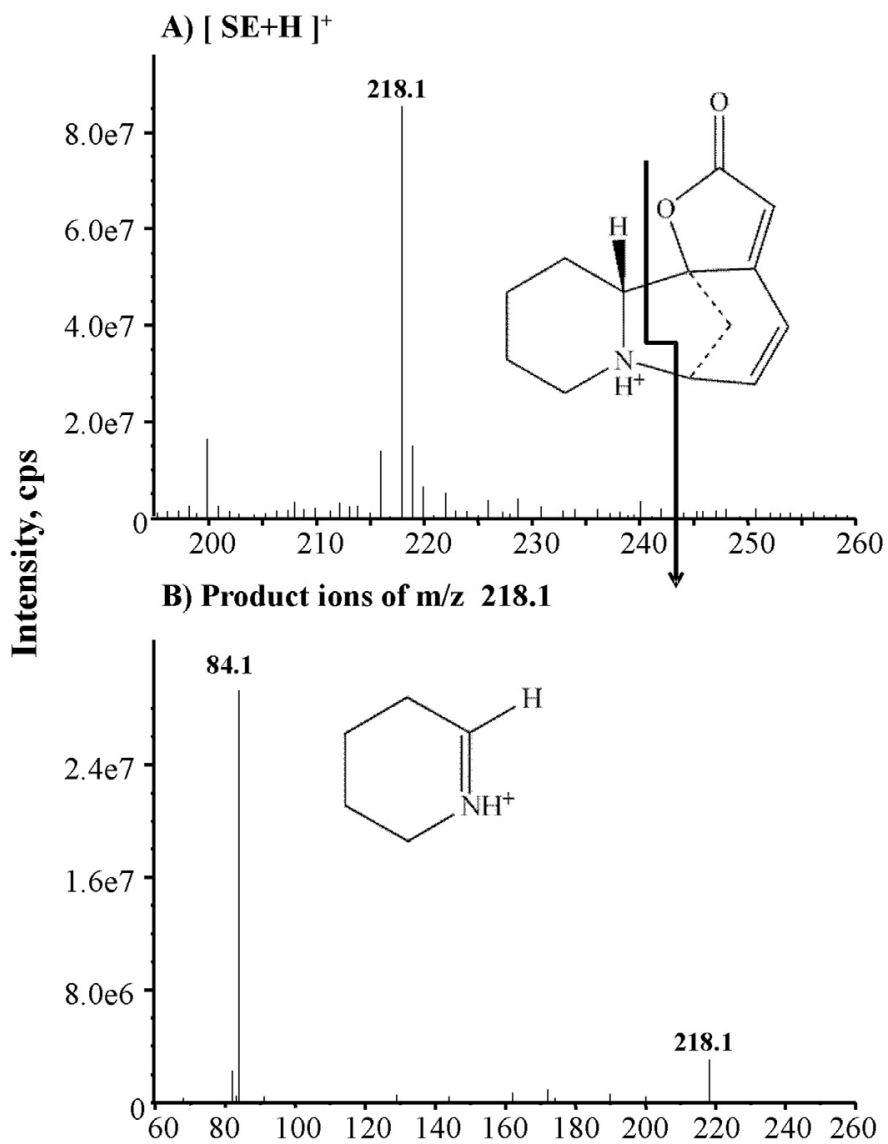

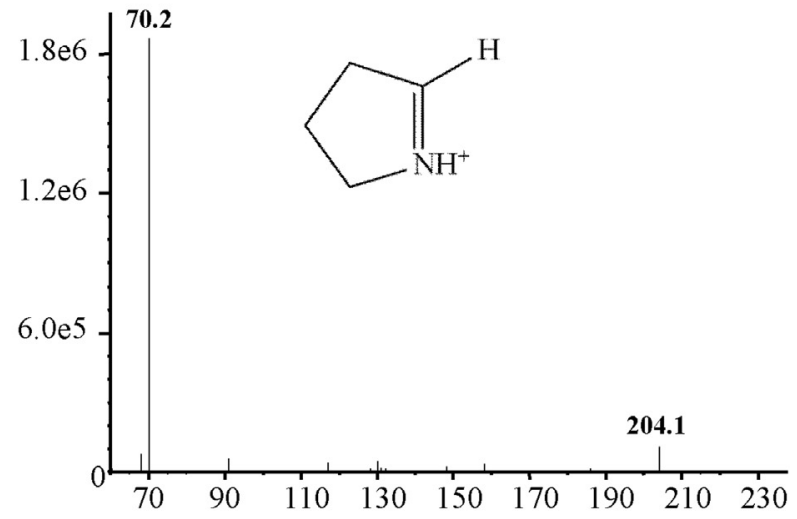

$m / z$

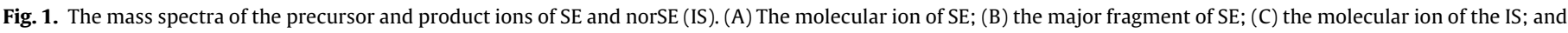
(D) the major fragment of the IS. 


\section{Mass spectrometric detection}

Due to the chemical structures of SE and norSE (IS), they are more readily to acquire protons than lose one in electrospray ionization. Hence, the positive electrospray ionization mode was used in this work. As shown in Fig. $1 \mathrm{~A}$ and $\mathrm{C}$ (full scan spectra), SE and norSE produced protonated molecular ions $[\mathrm{M}+\mathrm{H}]^{+}$at $\mathrm{m} / z 218.1$ and $m / z$ 204.1, respectively. These molecular ions produced major fragments (Fig. 1B and D) at $m / z 84.1$ and $m / z$ 70.2, respectively. Therefore, the mass transitions of $m / z 218.1 \rightarrow 84.1$ for SE and $m / z$ $204.1 \rightarrow 70.2$ for the IS were chosen for the MRM quantification. The assignments of the SE and norSE fragments in Fig. 1 were initially done by ACD/MS Fragmenter software (ACD Labs Toronto, Canada), and further confirmed by the experimental data.

\section{Chromatographic separation}

In this work, reverse-phase liquid chromatography (RP-LC) columns such as Waters Xterra ${ }^{\circledR}$ RP-18 and Phenomnex Gemini $\mathrm{Nx} \mathrm{C}_{18}$ (Phenomnex, Torrance, California) columns were tested for separation of SE and norSE. Either one was suitable for the work. Since the Gemini $\mathrm{Nx}_{18}$ gave higher signal intensity, it was chosen for this method.

The composition of the mobile phase used for separation was optimized. Acetonitrile was chosen as the organic solvent due to its greater solvent strength and higher signal response of analytes in mass spectrometry than those of methanol; and ammonium acetate $(10.0 \mathrm{mM})$ was used as the buffer because it suppressed the formation of sodium ion adducts and reduced peak tailing. Since the $\mathrm{pH}$ value of a mobile phase can influence the retention of amine derivatives on reverse phase column, the optimal $\mathrm{pH}$ of the mobile phase was investigated. In this work, baseline resolution of SE and norSE was achieved with ammonium acetate $(10.0 \mathrm{mM})$ at $\mathrm{pH} 6.8$. Under this $\mathrm{pH}$ value, both $\mathrm{SE}\left(\mathrm{p} K_{\mathrm{a}}=8.29\right)$ and norSE $\left(\mathrm{p} K_{\mathrm{a}}=8.78\right)$ were in their protonated forms.

A)

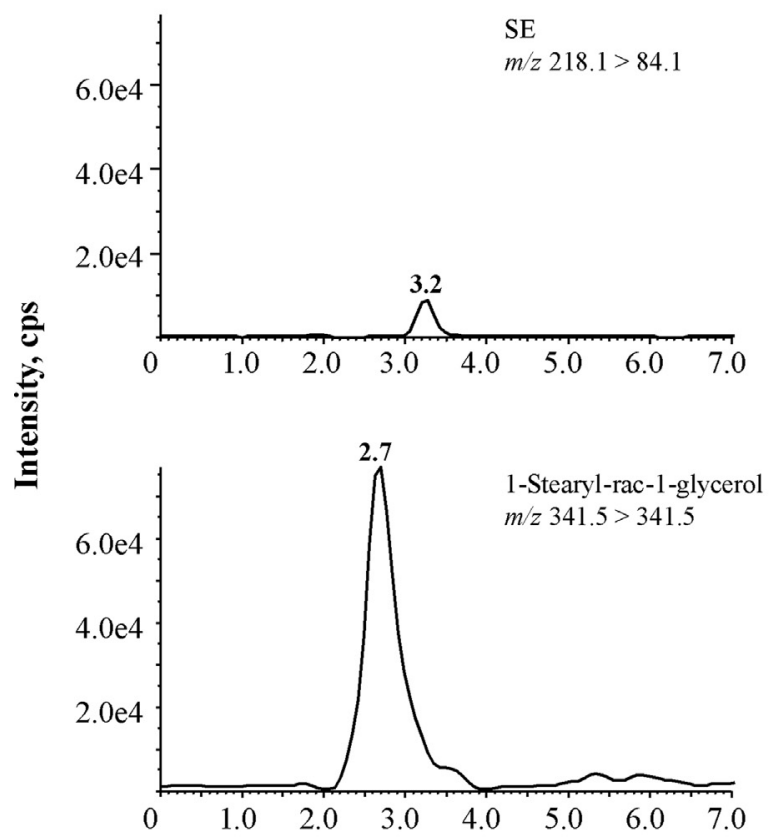

The percent content of acetonitrile in the mobile phase was also investigated. Initially $70 \%$ acetonitrile was used; although it produced shorter retention times for the analytes, it caused coelution of an endogenous lipid (2.7 min) with SE (3.2 min) in plasma sample, and resulted in significant ion suppression to SE (Fig. 2A). The lipid co-eluted was identified to be 1-stearyl-rac-1-glycerol (monoacylglycerol) [21]. To circumvent this problem, the percent content of acetonitrile was reduced to $40 \%$ by which no apparent 1-stearyl-rac-1-glycerol was observed near the retention time of SE (Fig. 2B).

For the LC-MS/MS method developed, the optimized mobile phase composition consisted of $40 \%$ acetonitrile and $60 \% 10.0 \mathrm{mM}$ ammonium acetate ( $\mathrm{pH}$ 6.8). Using this mobile phase, separation of $\mathrm{SE}$ and norSE could be achieved on the Gemini $\mathrm{Nx} \mathrm{C}_{18}$ with retention times of $2.6 \mathrm{~min}$ and $5.5 \mathrm{~min}$ for norSE and SE, respectively (Fig. 3).

\section{Preparation of plasma samples}

In this work, liquid-liquid extraction (LLE) was first examined for sample preparation. In detail, $100 \mu \mathrm{L}$ of plasma sample was first diluted with $0.05 \%$ ammonium aqueous solution to deprotonate the analytes, then $1.00 \mathrm{~mL}$ of ethyl acetate was added. The organic layer was transferred into borosilicate glass tubes $(12 \mathrm{~mm} \times 75 \mathrm{~mm}$, VWR) and dried under nitrogen (10 psi) by TurboVap LV evaporator (Zymark, Hopkinton, MA, USA) at $40^{\circ} \mathrm{C}$ for $30 \mathrm{~min}$, and reconstituted in the mobile phase for analysis. Due to the high volatilities of SE and norSE, cross-vial contamination was observed. Furthermore, the recoveries of analytes were low and the matrix effect was high by LLE. To overcome these problems, a salting-out assisted liquid-liquid extraction (SALLE) protocol was later adopted for plasma sample preparation $[22,23]$, where a concentrated volatile salt (i.e., $2.00 \mathrm{M}$ ammonium acetate) with a cold organic solvent (i.e., acetonitrile) were added to promote protein precipitation and induce phase separation. The analytes extracted were determined by LC-MS/MS after a direct dilution of the organic phase

\section{B)}
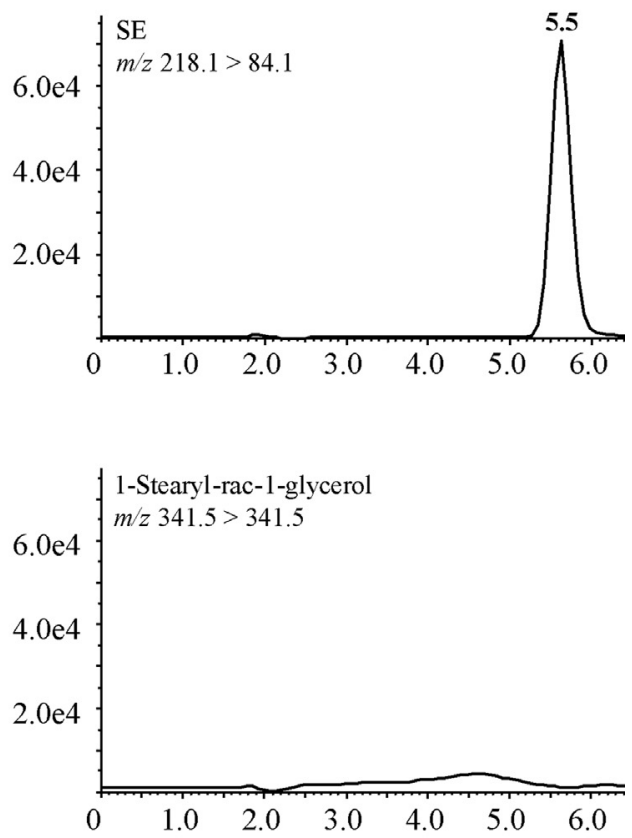

Time (min)

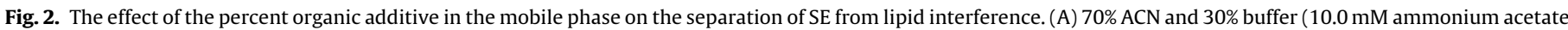

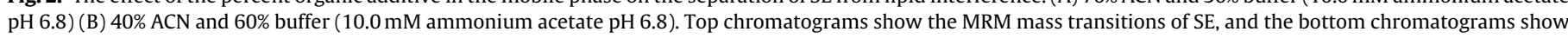
the MRM mass transitions of 1-stearyl-rac-1-glycerol (monoacyl glycerol). 

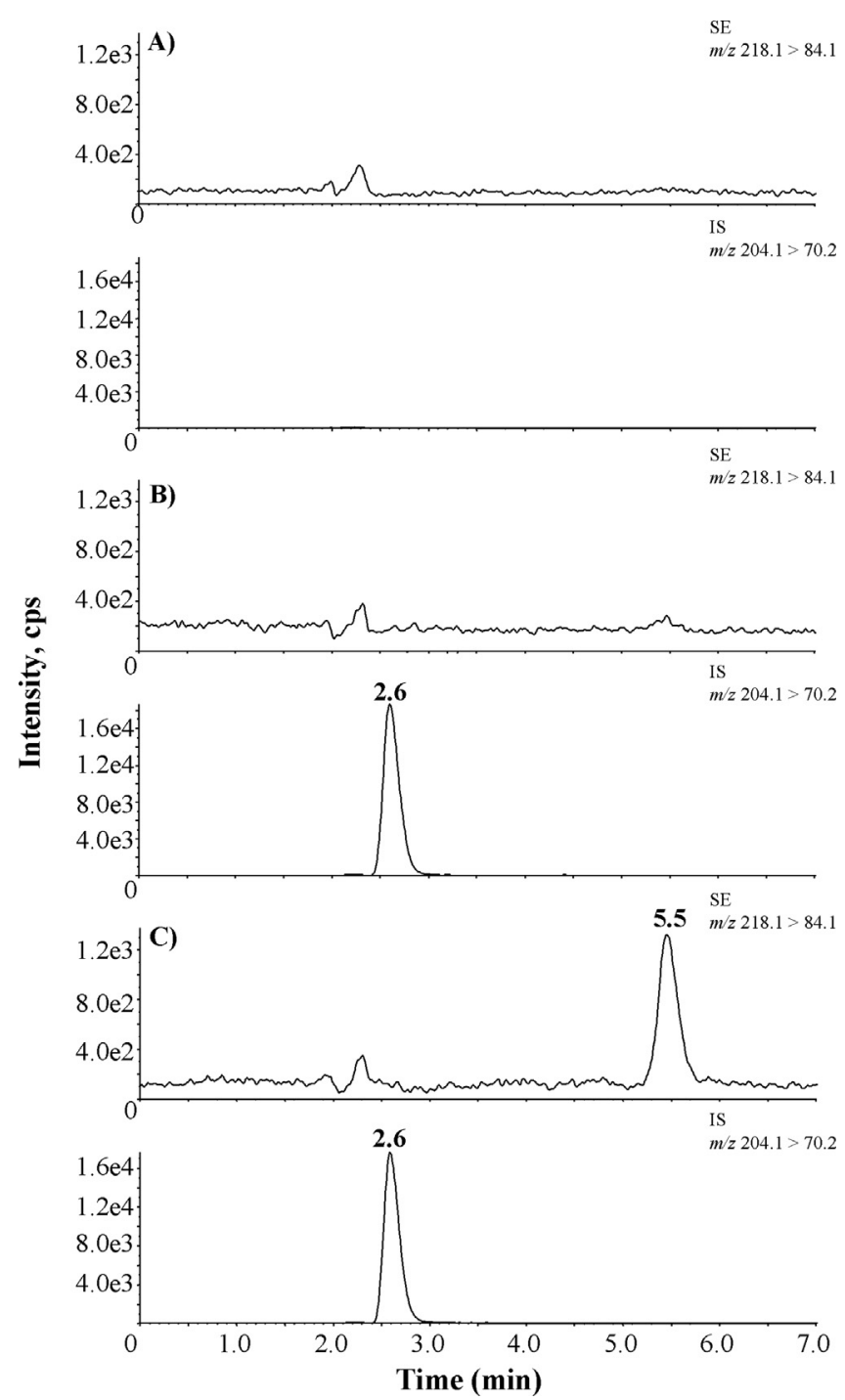

Fig. 3. The representative mass chromatograms of SE and the IS in mouse plasma: (A) double blank plasma (with neither SE nor IS); (B) single blank plasma (with IS only, $60 \mathrm{ng} \mathrm{mL}^{-1}$ ); and (C) at LLOQ (0.600 $\mathrm{ng} \mathrm{mL}^{-1}$; IS, $\left.60 \mathrm{ng} \mathrm{mL}^{-1}\right)$.

with $10.0 \mathrm{mM}$ ammonium acetate ( $\mathrm{pH}$ 6.8) buffer (at 1:1 ratio). The SALLE protocol was found to be effective in removal of matrix interference and producing good analyte recoveries (see data in Sections 3.6.2 and 3.6.3).

\section{Method validation}

The method developed was validated in mouse plasma according to the US-FDA guidance for industry on bioanalytical method validation [17] and the white paper of the 2006 bioanalytical method validation workshop $[18,19]$ in terms of selectivity, lower limit of quantitation, linear response range, recovery, matrix effect, accuracy and precision, as well as stability for both short-term sample processing and long-term sample storage.

\section{Selectivity and lower limit of quantitation (LLOQ)}

The selectivity of the method was evaluated by comparing the mass chromatograms of six lots of blank plasma samples with those of the spiked plasma calibrator at the LLOQ. In this work, there were no endogenous interference observed at the retention times and mass transitions of SE and the IS (Fig. 3A). Furthermore, there was
Table 1

Accuracy and precision of SE at LLOQ in six individual lots of mouse plasma $(n=5)$.

\begin{tabular}{llllrl}
\hline $\begin{array}{l}\text { Plasma } \\
\text { matrix }\end{array}$ & $\begin{array}{l}\text { Nominal } \\
{[\mathrm{SE}]} \\
\left(\mathrm{ng} \mathrm{mL} \mathrm{mL}^{-1}\right)\end{array}$ & $\begin{array}{l}\text { Mean } \\
\text { measured }[\mathrm{SE}] \\
\left(\mathrm{ng} \mathrm{mL}^{-1}\right)\end{array}$ & $\mathrm{SD}\left(\mathrm{ng} \mathrm{mL}^{-1}\right)$ & $\% \mathrm{RE}$ & $\% \mathrm{CV}$ \\
\hline Lot 1 & 0.600 & 0.61 & 0.02 & 2 & 3 \\
Lot 2 & 0.600 & 0.58 & 0.03 & -3 & 5 \\
Lot 3 & 0.600 & 0.57 & 0.01 & -5 & 2 \\
Lot 4 & 0.600 & 0.61 & 0.02 & 2 & 3 \\
Lot 5 & 0.600 & 0.56 & 0.02 & -7 & 4 \\
Lot 6 & 0.600 & 0.56 & 0.03 & -7 & 5 \\
\hline
\end{tabular}

Each datum point was calculated by five replicate measurements.

$\% \mathrm{RE}=[($ measured - nominal $) /($ nominal $)] \times 100 \% ; \% \mathrm{CV}=(\mathrm{SD} /$ mean $) \times 100 \%$.

no interference from the IS at the retention time and $m / z$ for SE (Fig. 3B).

The LLOQ of the method was defined by the lowest calibrator of the calibration curve $\left(0.600 \mathrm{ng} \mathrm{mL}^{-1}\right)$ (Fig. $\left.3 \mathrm{C}\right)$. As shown in Table 1 , the accuracy expressed as percent error (\%RE) and precision as correlation of variation ( $\% \mathrm{CV}$ ) were $\leq \pm 7 \%$ and $\leq 5 \%$ respectively, based on five replicate measurements in six lots of blank plasma matrices. Since the acceptable accuracy (\%RE) and precision (\%CV) were $\leq \pm 20 \%$ and $20 \%$, these results imply that the actual LLOQ of the method may be lower than $0.600 \mathrm{ng} \mathrm{mL}^{-1}$.

\section{Matrix effect}

The sample matrix effect was assessed by the matrix factor (MF) in six lots of mouse plasmas. The absolute MFs of SE and the IS were determined by comparing the mean-peak-area of SE and the IS in the spiked plasma matrix after SALLE $(n=5)$ with those of SE and the IS in the mobile phase at low- and high-QCs (1.80 and $540 \mathrm{ng} \mathrm{mL}^{-1}$ ). The IS normalized MF was determined by MFs of SE over those of the IS. As shown in Table 2, the absolute MFs of SE and the IS ranged from 0.99 to 1.15 and 1.01 to 1.10 respectively. The IS normalized MFs were in the range of $0.92-1.07$. These results indicate that the plasma matrix effect was negligible in this method.

\section{Analyte recovery by SALLE}

The absolute recoveries of SE and the IS were determined by comparing the mean-peak-area of SE and the IS in the corresponding QC plasma samples $(n=5)$ at low-, mid- and high-QC concentrations $\left(1.80,18.0,540 \mathrm{ng} \mathrm{mL}^{-1}\right)$ with those of SE and the IS in the spiked in plasma matrix after SALLE. The IS normalized recoveries were determined by the recoveries of SE over those of the IS. As shown in Table 3, the mean absolute recoveries for SE and the IS ranged $79-86 \%$ and $79-80 \%$, respectively; and the mean IS normalized recoveries ranged $99-109 \%$.

\section{Carryover}

The carryover of the analytes was assessed with five batches of validation calibrators by injecting pooled blank plasma (no SE and the IS) immediately after the injection of the plasma calibrator at the highest concentration (600 $\mathrm{ng} \mathrm{mL}^{-1}$ ). There were no analyte peaks observed using $90 \%$ acetonitrile as the injector needle washing solution. Hence, sample carryover was not a problem in this method.

\section{Accuracy and precision}

The intra-run accuracy and precision were determined by five replicate measurements of each low-, mid- and high- QC samples $\left(1.80,18.0,540 \mathrm{ng} \mathrm{mL}^{-1}\right)$ as well as dilution QC $\left(1.80 \times 10^{3} \mathrm{ng} \mathrm{mL}^{-1}\right)$ in the same validation batch. The inter-run accuracy and precision were determined by five parallel measurements of five identical sets of each QC samples over five different validation batches. As shown in Table 4, the intra-run accuracy and precisions of all 
Table 2

Matrix effect on SE in six individual lots of mouse plasma $(n=5)$.

\begin{tabular}{|c|c|c|c|c|}
\hline Plasma matrix & {$[\mathrm{SE}]\left(\mathrm{ng} \mathrm{mL} \mathrm{m}^{-1}\right)$} & $\mathrm{MF}_{\mathrm{SE}} \pm \mathrm{SD}^{\mathrm{a}}$ & $\mathrm{MF}_{\mathrm{IS}} \pm \mathrm{SD}^{\mathrm{b}}$ & IS normalized $\mathrm{MF} \pm \mathrm{SD}^{\mathrm{c}}$ \\
\hline Lot 1 & $\begin{array}{l}1.80 \\
540\end{array}$ & $\begin{array}{l}1.03 \pm 0.02 \\
1.05 \pm 0.05\end{array}$ & $\begin{array}{l}1.04 \pm 0.04 \\
1.09 \pm 0.05\end{array}$ & $\begin{array}{l}0.98 \pm 0.03 \\
0.96 \pm 0.03\end{array}$ \\
\hline Lot 2 & $\begin{array}{l}1.80 \\
540\end{array}$ & $\begin{array}{l}1.02 \pm 0.03 \\
1.01 \pm 0.05\end{array}$ & $\begin{array}{l}1.04 \pm 0.02 \\
1.10 \pm 0.06\end{array}$ & $\begin{array}{l}0.98 \pm 0.02 \\
0.92 \pm 0.04\end{array}$ \\
\hline Lot 3 & $\begin{array}{l}1.80 \\
540\end{array}$ & $\begin{array}{l}1.03 \pm 0.03 \\
1.03 \pm 0.03\end{array}$ & $\begin{array}{l}1.03 \pm 0.04 \\
1.03 \pm 0.04\end{array}$ & $\begin{array}{l}0.99 \pm 0.02 \\
0.99 \pm 0.02\end{array}$ \\
\hline Lot 4 & $\begin{array}{l}1.80 \\
540\end{array}$ & $\begin{array}{l}1.05 \pm 0.03 \\
0.99 \pm 0.06\end{array}$ & $\begin{array}{l}1.05 \pm 0.03 \\
1.06 \pm 0.03\end{array}$ & $\begin{array}{l}1.01 \pm 0.02 \\
0.93 \pm 0.07\end{array}$ \\
\hline Lot 5 & $\begin{array}{l}1.80 \\
540\end{array}$ & $\begin{array}{l}1.01 \pm 0.01 \\
1.02 \pm 0.01\end{array}$ & $\begin{array}{l}1.09 \pm 0.02 \\
1.01 \pm 0.08\end{array}$ & $\begin{array}{l}0.92 \pm 0.02 \\
1.01 \pm 0.09\end{array}$ \\
\hline Lot 6 & $\begin{array}{l}1.80 \\
540\end{array}$ & $\begin{array}{l}1.15 \pm 0.04 \\
1.02 \pm 0.01\end{array}$ & $\begin{array}{l}1.08 \pm 0.02 \\
1.02 \pm 0.06\end{array}$ & $\begin{array}{l}1.07 \pm 0.04 \\
1.00 \pm 0.05\end{array}$ \\
\hline
\end{tabular}

${ }^{\text {a }} \mathrm{MF}_{\mathrm{SE}}=$ (mean peak area of SE in extracted plasma matrix)/(mean peak area of SE in mobile phase).

b $\mathrm{MF}_{\mathrm{IS}}=$ (mean peak area of the IS in extracted plasma matrix)/(mean peak area of the IS in mobile phase).

c IS normalized $\mathrm{MF}=\mathrm{MF}_{\mathrm{SE}} / \mathrm{MF}_{\mathrm{IS}}$.

Table 3

Recovery of SE in pooled mouse plasma $(n=5)$.

\begin{tabular}{clll}
\hline$[\mathrm{SE}]\left(\mathrm{ng} \mathrm{mL} \mathrm{mL}^{-1}\right)$ & $\begin{array}{l}\text { RecoverysE } \pm \text { SD } \\
(\%)\end{array}$ & $\begin{array}{l}\text { Recovery } \\
(\%)\end{array}$ & $\begin{array}{l}\text { IS normalized } \\
\text { Recovery } \pm \text { SD }(\%)\end{array}$ \\
\hline 1.80 & $86 \pm 3$ & $79 \pm 2$ & $109 \pm 2$ \\
18.0 & $84 \pm 3$ & $79 \pm 1$ & $107 \pm 3$ \\
540 & $79 \pm 2$ & $80 \pm 3$ & $99 \pm 2$ \\
\hline
\end{tabular}

$\mathrm{PA}=$ mean peak area.

Recovery of $\mathrm{SE}=(\mathrm{PA}$ of $\mathrm{SE}$ in plasma matrix $/ \mathrm{PA}$ of $\mathrm{SE}$ in extracted plasma matrix) $\times 100 \%$.

Recovery of IS $=(\mathrm{PA}$ of IS in plasma matrix $/ \mathrm{PA}$ of IS in extracted plasma matrix) $\times 100 \%$.

IS normalized recovery $=($ recovery of SE/recovery of the IS $) \times 100 \%$.

Table 4

Intra- and inter-run accuracy and precision of SE in pooled mouse plasma $(n=5)$.

\begin{tabular}{lcccc}
\hline $\begin{array}{l}\text { Nominal [SE] } \\
\left.(\mathrm{ng} \mathrm{mL})^{-1}\right)\end{array}$ & $\begin{array}{l}\text { Measured [SE] } \\
\left.(\mathrm{ng} \mathrm{mL})^{-1}\right)\end{array}$ & $\mathrm{SD}\left(\mathrm{ng} \mathrm{mL}^{-1}\right)$ & $\% \mathrm{RE}$ & $\% \mathrm{CV}$ \\
\hline $\begin{array}{l}\text { Intra-run }^{\mathrm{a}} \\
1.80\end{array}$ & 1.8 & & & \\
18.0 & 17.0 & 0.1 & 0.0 & 6 \\
540 & 545 & 6 & -6 & 3 \\
$1.80 \times 10^{3 \mathrm{c}}$ & $1.75 \times 10^{3}$ & $8 \times 10^{1}$ & -3 & 5 \\
Inter-run b $_{1.80}$ & & & & \\
18.0 & 1.7 & 0.1 & -6 & 6 \\
540 & 17.0 & 0.4 & -6 & 2 \\
$1.80 \times 10^{3 \mathrm{c}}$ & 549 & 8 & 2 & 1 \\
& $1.91 \times 10^{3}$ & $7 \times 10^{1}$ & 6 & 4
\end{tabular}

a Determined by five replicate measurements of each QC sample within a validation batch.

b Determined by five parallel measurements of five identical QC samples at each concentration over five validation batches.

c The dilution QC was measured after 10 times dilution with the pooled blank plasma.

Table 5

Accuracy and precision of SE plasma calibrators over five validation batches.

\begin{tabular}{cclcc}
\hline $\begin{array}{l}\text { Nominal [SE] } \\
\left.(\mathrm{ng} \mathrm{mL})^{-1}\right)\end{array}$ & $\begin{array}{l}\text { Measured [SE] } \\
\left(\mathrm{ng} \mathrm{mL}^{-1}\right)\end{array}$ & $\begin{array}{l}\mathrm{SD} \\
\left(\mathrm{ng} \mathrm{mL}^{-1}\right)\end{array}$ & $\% \mathrm{RE}$ & $\% \mathrm{CV}$ \\
\hline 0.600 & 0.59 & 0.02 & -2 & 3 \\
1.20 & 1.20 & 0.06 & 0.0 & 5 \\
6.00 & 6.00 & 0.3 & 0.0 & 5 \\
12.0 & 11.9 & 0.7 & -1 & 6 \\
60.0 & 62.0 & 4.0 & 3 & 6 \\
120 & 120 & 5 & 0.0 & 4 \\
600 & 597 & 7 & -0.5 & 1 \\
\hline
\end{tabular}

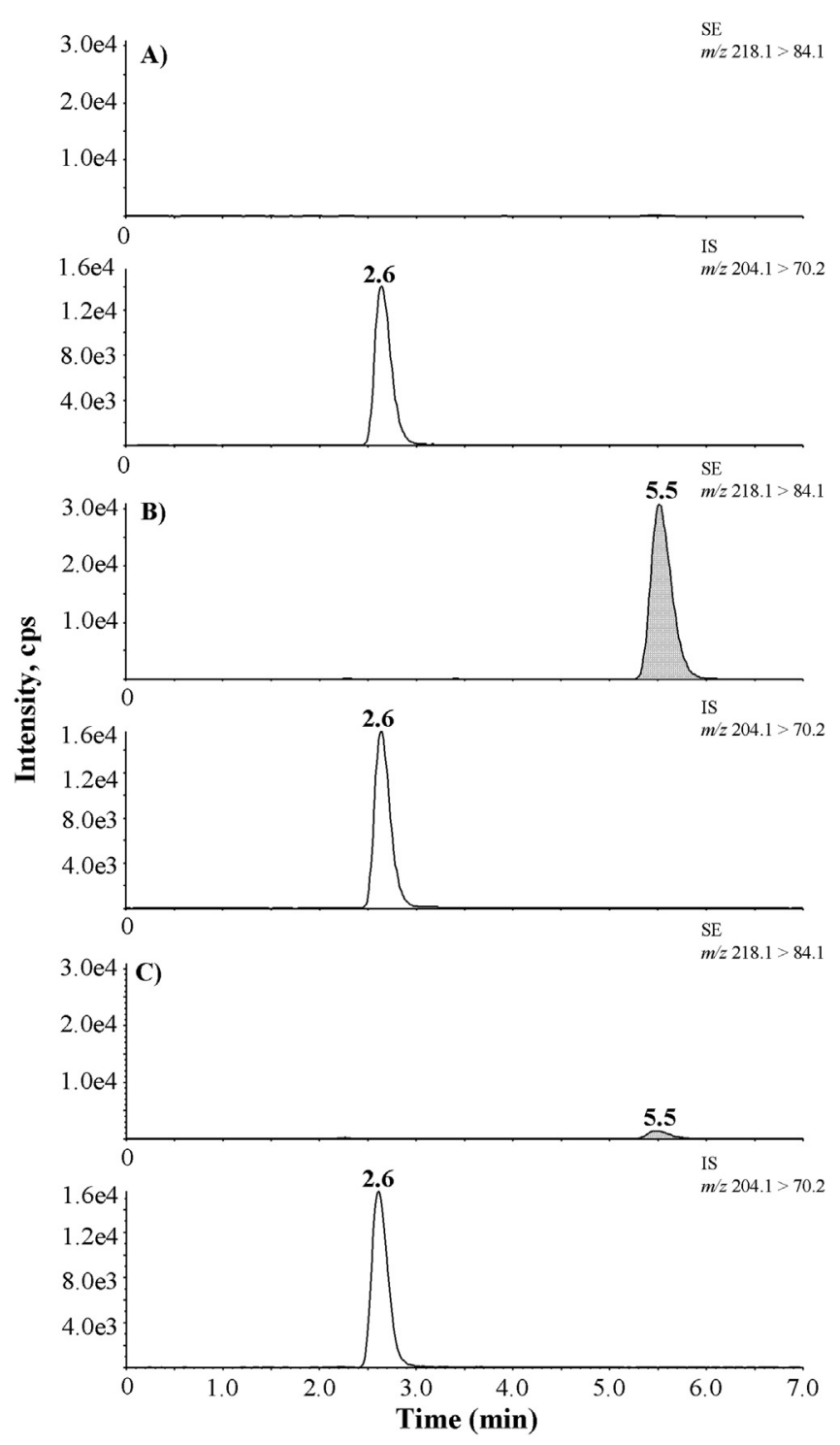

Fig. 4. The representative mass chromatograms of animal study. (A) Predosed mouse plasma (run with $60 \mathrm{ng} \mathrm{mL}^{-1}$ IS); (B) plasma sample collected at 3 min after i.p. injection (run with $60 \mathrm{ng} \mathrm{mL}^{-1}$ IS); and (C) plasma sample collected $30 \mathrm{~min}$ after i.p. injection (run with $60 \mathrm{ng} \mathrm{mL}^{-1} \mathrm{IS}$ ). 
the QCs samples were $\leq \pm 6 \%$ and $\leq 6 \%$, and the inter-run accuracy and precisions were $\leq \pm 6 \%$ and $\leq 6 \%$ respectively. These results indicate that the method developed has adequate accuracy and precision.

\section{Linearity}

The calibration curve of SE in mouse plasma was constructed using a double blank (with neither SE nor IS), a single blank (zero calibrator, with IS) and seven non-zero SE plasma calibrators $\left(0.600,1.20,6.00,12.0,60.0,120\right.$ and $\left.600 \mathrm{ng} \mathrm{mL}^{-1}\right)$, with the concentration of the IS at $60.0 \mathrm{ng} \mathrm{mL}^{-1}$. The mean-peak-area ratios of SE to those of IS were plotted against the nominal concentration of SE. The calibration equation derived from five validation batches using $1 / x$ weighted least-square linear regression was $Y=0.135( \pm 0.009) x+0.009( \pm 0.008)$. A linear range of over three orders of magnitude $\left(0.600-600 \mathrm{ng} \mathrm{mL}^{-1}\right)$ was obtained with a correlation coefficient of 1.00 , and the accuracy and precision of plasma calibrators were $\leq \pm 3$ and $\leq 6$, respectively (Table 5).

\section{Stability study}

The stabilities of SE and norSE under various storage conditions were assessed. As shown in Table 6, the recoveries for SE stock solution $\left(23^{\circ} \mathrm{C}\right)$ were $100 \%$ and $103 \%$ at $6 \mathrm{~h}$ and $24 \mathrm{~h}$, and $105 \%$ by long term storage $\left(-80^{\circ} \mathrm{C}, 5\right.$ months $)$. The recoveries for SE plasma QCs were $94-101 \%$ on bench-top $\left(23^{\circ} \mathrm{C}\right)$ and $100-104 \%$ in auto sampler $\left(4^{\circ} \mathrm{C}\right)$ within $24 \mathrm{~h}$. The recoveries of SE plasma QCs by three freeze-and-thaw cycles $\left(-20\right.$ to $\left.23^{\circ} \mathrm{C}\right)$ and long-term storage at $-80{ }^{\circ} \mathrm{C}$ ( 30 days) were $97-99 \%$ and $97-99 \%$, respectively. However, it should be noted that the recoveries of SE plasma QCs by long term storage at $-20^{\circ} \mathrm{C}$ for 30 days were rather low (76-79\%). Therefore, plasma samples should be kept at $-80^{\circ} \mathrm{C}$ for long term storage, and plasma samples should be analyzed within $24 \mathrm{~h}$ timeframe after thawing.

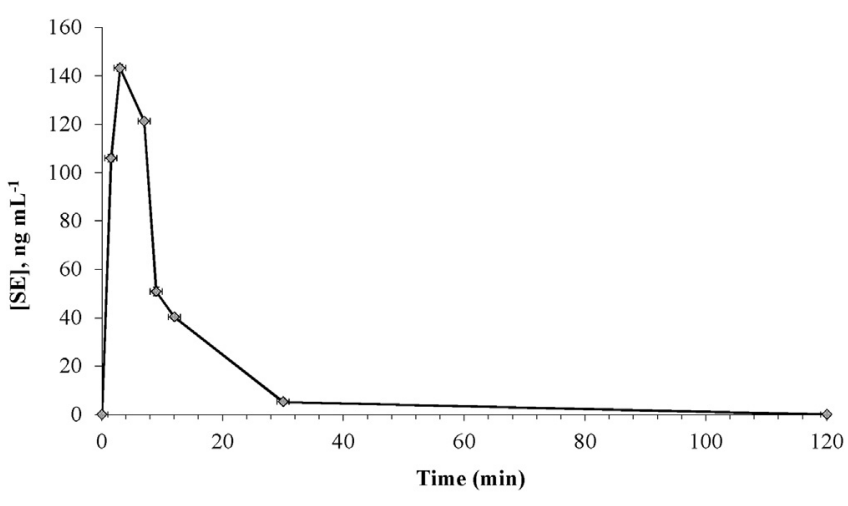

Fig. 5. The mean concentration-time profile of SE in mouse plasma $(n=3)$ after single i.p. bolus injection at the dose of $4 \mathrm{mg} \mathrm{kg}^{-1}$.

The recoveries of norSE under various conditions were in the range of $96-105 \%$, which indicated that no significant loss of norSE was observed under the experimental conditions.

\section{Method application}

The validated LC-MS/MS method was applied to the measurement of plasma concentrations of SE in BALB/C mice. The animal samples were collected and analyzed by the procedure described in the experimental section. The representative mass chromatograms of SE in mouse plasma from the animal study are shown in Fig. 4. The concentration of SE in each mouse sample was back calculated using the peak-area ratio of SE to that of the IS from the calibration equation with the proper dilution factor. Fig. 5 shows the mean SE plasma concentration-time profile in mice $(n=3)$ after a single bolus i.p. injection of $4 \mathrm{mg} \mathrm{kg}^{-1} \mathrm{SE}$, which demonstrated the applicability of the method for pharmacokinetic study in mice.

Table 6

Stability of SE and the IS in mouse plasma samples under various conditions.

\begin{tabular}{|c|c|c|c|c|c|}
\hline \multirow[t]{2}{*}{ Test conditions } & \multirow[t]{2}{*}{ Temperature $\left({ }^{\circ} \mathrm{C}\right)$} & \multirow[t]{2}{*}{$\mathrm{SE}^{\mathrm{a}}$} & \multicolumn{3}{|c|}{ Recovery \pm SD $(\%)(n=3)$} \\
\hline & & & $6 \mathrm{~h}$ & $24 \mathrm{~h}$ & \\
\hline Bench-top & 23 & Stock solution & $100 \pm 1$ & $103 \pm 1$ & \\
\hline Freezer (5 months) & -80 & Stock solution & & & $105 \pm 2$ \\
\hline Bench-top & 23 & $\begin{array}{l}\text { Low QC } \\
\text { High QC }\end{array}$ & $\begin{array}{l}100 \pm 2 \\
101 \pm 5\end{array}$ & $\begin{array}{l}96 \pm 4 \\
94 \pm 3\end{array}$ & \\
\hline Autosampler & 4 & $\begin{array}{l}\text { Low QC } \\
\text { High QC }\end{array}$ & $\begin{array}{l}100 \pm 2 \\
100 \pm 3\end{array}$ & $\begin{array}{l}104 \pm 7 \\
103 \pm 3\end{array}$ & \\
\hline 3 Freeze-thaw cycles & -20 to 23 & $\begin{array}{l}\text { Low QC } \\
\text { High QC }\end{array}$ & & & $\begin{array}{l}97 \pm 2 \\
99 \pm 4\end{array}$ \\
\hline Long-term (30 days) & -20 & $\begin{array}{l}\text { Low QC } \\
\text { High QC }\end{array}$ & & & $\begin{array}{l}76 \pm 3 \\
79 \pm 3\end{array}$ \\
\hline Long-term (30 days) & -80 & $\begin{array}{l}\text { Low QC } \\
\text { High QC }\end{array}$ & & & $\begin{array}{l}99 \pm 3 \\
97 \pm 3\end{array}$ \\
\hline \multirow[t]{2}{*}{ Test conditions } & Temperature $\left({ }^{\circ} \mathrm{C}\right)$ & NorSE $^{b}$ & \multicolumn{3}{|c|}{ Recovery \pm SD $(\%)(n=3)$} \\
\hline & & & $6 h$ & $24 \mathrm{~h}$ & \\
\hline Bench-top & 23 & Stock solution & $104 \pm 5$ & $101 \pm 5$ & \\
\hline Bench-top & 23 & Plasma sample & $102 \pm 6$ & $103 \pm 3$ & \\
\hline Autosampler & 4 & Plasma sample & $101 \pm 7$ & $105 \pm 4$ & \\
\hline 3 freeze-thaw cycles & -20 to 23 & Plasma sample & & & $96 \pm 5$ \\
\hline
\end{tabular}

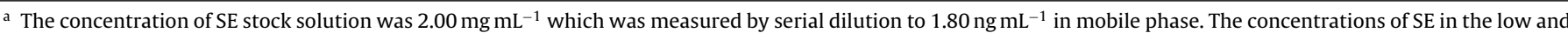
high QCs were 1.80 and $540 \mathrm{ng} \mathrm{mL}^{-1}$, respectively.

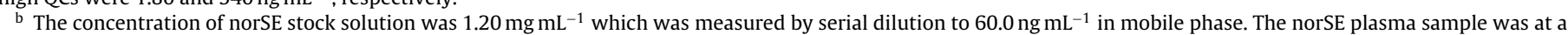
concentration of $60.0 \mathrm{ng} \mathrm{mL}^{-1}$. 


\section{Conclusions}

An LC-MS/MS method for quantitative determination of SE in mouse plasma has been developed and validated. The method uses SALLE procedure for sample preparation, reverse phase-liquid chromatography for separation, and tandem mass spectrometry for detection. The method has good analyte selectivity, wide linear calibration range, and high accuracy and precisions. It has been applied to the measurement of SE in mouse plasma samples; therefore, maybe be useful for the pharmacological study of SE in mice.

\section{Acknowledgements}

SLW is grateful for the financial support of the fellowship from the Cellular Molecular Medicine Program and the Doctoral Dissertation Research Expense Award from Cleveland State University. This work was supported by the National Science Foundation MRI Grant (CHE-2923308) to YX.

\section{References}

[1] D. Raj, M. Luczkiewicz, Fitoterapia 79 (2008) 419-427.

[2] S. Saito, T. Tanaka, T. Iwamoto, C. Matsumura, N. Sugimoto, Z. Horii, M. Makita, M. Ikeda, Y. Tamura, Yakugaku Zasshi 84 (1964) 1126-1133.

[3] J.A. Beutler, E.W. Karbon, A.N. Brubaker, R. Malik, D.R. Curtis, S.J. Enna, Brain Res. 330 (1985) 135-140.

[4] D. Rognan, T. Boulanger, R. Hoffmann, D.P. Vercauteren, J.M. Andre, F. Durant, C.G. Wermuth, J. Med. Chem. 35 (1992) 1969-1977.
[5] H. Guan, S. You, L. Yang, X. Wang, R. Ni, Biotechnol. Lett. 27 (2005) 1189-1193.

[6] R. Copperman, G. Copperman, A. Der Marderosian, Pa. Med. 76 (1973) 36-41.

[7] K. Lubick, M. Radke, M. Jutila, J. Leukoc. Biol. 82 (2007) 1062-1069.

[8] M. Holmes, A.K. Crater, B. Dhudshia, A.N. Thadani, S. Ananvoranich, Exp. Parasitol. 127 (2011) 370-375.

[9] N.Z. Dong, Z.L. Gu, W.H. Chou, C.Y. Kwok, Zhongguo Yao Li Xue Bao 20 (1999) 267-270.

[10] Y.H. Xia, C.R. Cheng, S.Y. Yao, Q. Zhang, Y. Wang, Z.N. Ji, Fitoterapia 82 (2011) $1258-1264$.

[11] S. Rana, K. Gupta, J. Gomez, S. Matsuyama, A. Chakrabarti, M.L. Agarwal, A. Agarwal, M.K. Agarwal, D.N. Wald, FASEB J. 24 (2010) 2126-2134.

[12] K. Gupta, A. Chakrabarti, S. Rana, R. Ramdeo, B.L. Roth, M.L. Agarwal, W. Tse, M.K. Agarwal, D.N. Wald, PLoS ONE 6 (2011) e21203, http://dx.doi.org/ 10.1371/journal.pone.0021203.

[13] Y. Xue, H. Yuan, Yaowu Fenxi Zazhi 23 (2003) 94-96, 97.

[14] X.H. Li, J.L. Zhang, T.H. Zhou, Yao Xue Xue Bao 37 (2002) 288-293.

[15] X. Li, J. Zhang, T. Zhou, Yao Xue Xue Bao 37 (2002) 50-53.

[16] L. Shen, Y. Xu, Y. Wu, S. Wang, C. Zhang, Fenxi Huaxue 23 (1995) 1193-1196.

[17] U.S. Food and Drug Administration (FDA), Center for Drug Evaluation and Research (CDER), Guidance for Industry: Bioanalytical Method Validation, 2001, available at: http:/www.fda.gov/downloads/Drugs/ GuidanceComplianceRegulatoryInformation/Guidances/UCM070107.pdf (accessed 12.08.13).

[18] C.T. Viswanathan, S. Bansal, B. Booth, A.J. DeStefano, M.J. Rose, J. Sailstad, V.P. Shah, J.P. Skelly, P.G. Swann, R. Weiner, Pharm. Res. 24 (2007) 1962-1973.

[19] S. Bansal, A. DeStefano, AAPS J. 9 (2007) E109-E114, http://dx.doi.org/10.1208/aapsj0901011.

[20] M. McCulloch, X. Zhou, Y. Xu, S. Brunell, L. Spear, J. Chromatogr. B: Analyt. Technol. Biomed. Life Sci. 863 (2008) 258-265.

[21] O.A. Ismaiel, T. Zhang, R.G. Jenkins, H.T. Karnes, J. Chromatogr. B: Analyt. Technol. Biomed. Life Sci. 878 (2010) 3303-3316.

[22] A.M. Rustum, J. Chromatogr. 490 (1989) 365-375.

[23] H. Wu, J. Zhang, K. Norem, T.A. El-Shourbagy, J. Pharm. Biomed. Anal. 48 (2008) 1243-1248 